Article

\title{
Preparation, Identification, and Activity Evaluation of Eight Antioxidant Peptides from Protein Hydrolysate of Hairtail (Trichiurus japonicas) Muscle
}

\author{
Xiu-Rong Yang ${ }^{1}$, Lun Zhang ${ }^{1}$, Dong-Ge Ding ${ }^{1}$, Chang-Feng Chi ${ }^{2, * \mathbb{D}}$, Bin Wang ${ }^{1, *}$ and \\ Jian-Cong Huo ${ }^{1}$ \\ 1 Zhejiang Provincial Engineering Technology Research Center of Marine Biomedical Products, School of \\ Food and Pharmacy, Zhejiang Ocean University, 1st Haidanan Road, Zhoushan 316022, China; \\ yxr1948008999@163.com (X.-R.Y.); Z115525864652@163.com (L.Z.); 9001000@163.com (D.-G.D.); \\ yujia0112@sina.com (J.-C.H.) \\ 2 National and Provincial Joint Laboratory of Exploration and Utilization of Marine Aquatic Genetic \\ Resources, National Engineering Research Center of Marine Facilities Aquaculture, School of Marine Science \\ and Technology, Zhejiang Ocean University, 1st Haidanan Road, Zhoushan 316022, China \\ * Correspondence: chichangfeng@hotmail.com (C.-F.C.); wangbin4159@hotmail.com (B.W.); \\ Tel./Fax: +86-580-255-4818 (C.-F.C.); Tel./Fax: +86-580-255-4781 (B.W.)
}

Received: 12 November 2018; Accepted: 26 December 2018; Published: 2 January 2019

\begin{abstract}
In this report, protein of hairtail (Trichiurus japonicas) muscle was separately hydrolyzed using five kinds of proteases (alcalase, trypsin, neutrase, pepsin, and papain), and the papain- and alcalase-hydrolysates showed higher 2,2-diphenyl-1-picrylhydrazyl radicals (DPPH•) and hydroxyl radical (HO•) scavenging activity than other three protease hydrolysates. Therefore, the protein hydrolysate of hairtail muscle (HTP) was prepared using binary-enzymes hydrolysis process (papain + alcalase). Subsequently, eight antioxidant peptides were purified from HTP using membrane ultrafiltration and chromatography technology, and their amino acid sequences were identified as Gln-Asn-Asp-Glu-Arg (TJP1), Lys-Ser (TJP2), Lys-Ala (TJP3), Ala-Lys-Gly (TJP4), Thr-Lys-Ala (TJP5), Val-Lys (TJP6), Met-Lys (TJP7), and Ile-Tyr-Gly (TJP8) with molecular weights of 660.3, 233.0, 217.1, 274.1, 318.0, 245.1, 277.0, and 351.0 Da, respectively. TJP3, TJP4, and TJP8 exhibited strong scavenging activities on DPPH• $\left(\mathrm{EC}_{50} 0.902,0.626\right.$, and $0.663 \mathrm{mg} / \mathrm{mL}$, respectively), $\mathrm{HO} \bullet\left(\mathrm{EC}_{50} 1.740,2.378\right.$, and $2.498 \mathrm{mg} / \mathrm{mL}$, respectively), superoxide anion radical $\left(\mathrm{EC}_{50} 2.082,2.538\right.$, and $1.355 \mathrm{mg} / \mathrm{mL}$, respectively), and 2,2'-azino-bis-3-ethylbenzothiazoline-6-sulfonic acid (ABTS) radical (EC 50 1.652, 0.831 , and $0.586 \mathrm{mg} / \mathrm{mL}$, respectively). Moreover, TJP3, TJP4, and TJP8 showed higher reducing power and inhibiting ability on lipid peroxidation in a linoleic acid model system. These results suggested that eight isolated peptides (TJP1 to TJP8), especially TJP3, TJP4, and TJP8 might serve as potential antioxidants applied in the pharmaceutical and health food industries.
\end{abstract}

Keywords: hairtail (Trichiurus japonicas); muscle; peptide; antioxidant activity

\section{Introduction}

Reactive oxygen species (ROS) such as superoxide anion radical $\left(\mathrm{O}_{2}^{-} \bullet\right)$, hydrogen peroxide $\left(\mathrm{H}_{2} \mathrm{O}_{2}\right)$, hydroxyl radical $(\mathrm{HO} \bullet)$, and singlet oxygen $\left({ }^{1} \mathrm{O}_{2}\right)$, are formed in aerobic organisms as a natural by-product of oxygen metabolism and play vital roles in the physiological processes involved in signal transduction and homeostasis [1,2]. Under normal conditions, superfluous ROS are effectively eliminated by antioxidant enzymes and non-enzymatic factors in organisms [3]. An imbalance in pro-oxidant/antioxidant can induce oxidative stress, trigger accumulated ROS production, and result in cell damage and many health disorders, such as diabetes mellitus, coronary heart diseases, cancer, 
hepatic diseases, and inflammatory diseases [4,5]. Additionally, oxidation is believed to the major course of food deterioration because ROS-mediated oxidation can react with lipids, proteins, amino acids, vitamins, and cholesterol to produce undesirable off-flavors, and potentially toxicity during food processing, transportation, and storage [3,6]. Therefore, it is very important for pharmaceutical, health food, and food processing and preservation industries to develop efficient antioxidants [7]. At present, some artificial antioxidants including butylated hydroxytoluene (BHT), butylated hydroxyanisole (BHA), and tertiary butylhydroquinone (TBHQ) show stronger antioxidant activities and have been widely used in medicine and food industry for retarding oxidation in organisms and food $[4,7]$. However, the side effects of synthetic antioxidants such as liver damage and carcinogenesis causes consumer anxiety and significantly affect their application $[7,8]$. Therefore, there has been a major interest in searching for efficient antioxidants from natural sources as alternatives to synthetic antioxidants for countering these adverse effects.

At present, dietary antioxidant ingredients including vitamins, carotenoids, flavonoids, phenols, saccharides, and peptides, have been continually investigated for their health benefits in terms of their scavenging potential of free radicals and low toxicity [9]. Among them, bioactive peptides released from food proteins under controlled proteolysis have aroused wide public concern not only in their possibilities as natural alternatives to synthetic antioxidants, but also for their beneficial effects, lack of residual side effects, and functionality in food systems [10].

Antioxidant peptides from food resources are inactive in the amino acid sequence of their parent proteins and are produced by in vitro enzymatic hydrolysis [7]. These peptides with 2 to 20 amino acid residues are considered to be easy absorption and no hazardous immunoreactions. More importantly, antioxidant peptides can exert their activity as free radical scavengers, peroxide decomposers, metal inactivators and oxygen inhibitors to protect food and organisms from ROS [11-13]. In recent years, antioxidant peptides derived from seafood were more attractive and have been isolated and identified from diverse marine organisms, such as swim bladders of miiuy croaker (Miichthys miiuy) [6], bluefin leatherjacket (Navodon septentrionalis) heads and skin [8,14], thornback ray skins [15], Palmaria palmate [16], viscera and carcass of Nile tilapia [17], Pinctada fucata [18], pectoral fin of salmon [19], and jellyfish gonad [20]. Zhao et al. isolated ten antioxidant peptides from swim bladders of miiuy croaker, and PYLRH and GIEWA exhibited stronger scavenging

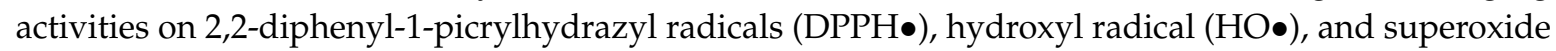
anion radical $\left(\mathrm{O}_{2}^{-} \bullet\right)$ than other eight peptides. Furthermore, FPYLRH and GIEWA could effectively inhibit lipid peroxidation in the $\beta$-carotene linoleic acid and in the linoleic acid emulsion system [6]. Harnedy et al. prepared and identified 17 peptides from the macroalgal species Palmaria palmata, and SDITRPGGNM showed the highest oxygen radical absorbance capacity and ferric reducing antioxidant power activity with values of $152.43 \pm 2.73$ and $21.23 \pm 0.90 \mathrm{nmol} \mathrm{TE} / \mu \mathrm{mol}$ peptide, respectively [16]. MCLDSCLL (P1) and HPLDSLCL (P2) showed potent antioxidant activities against DPPH• and 2,2'-azinobis-(3-ethylbenzothiazoline-6-sulfonic acid) (ABTS) radical (ABTS ${ }^{+} \bullet$ ) and inhibiting copper-catalyzed human low-density lipoprotein (LDL) oxidation [21]. GAERP, GEREANVM, and AEVG from cartilage protein hydrolysate of spotless smoothhound exhibited good scavenging activities on DPPH $\bullet, \mathrm{HO} \bullet, \mathrm{ABTS}^{+} \bullet$, and $\mathrm{O}_{2}^{-} \bullet$. Furthermore, GAERP, GEREANVM, and AEVG could protect $\mathrm{H}_{2} \mathrm{O}_{2}$-induced HepG2 cells from oxidative stress by decreasing the content of malonaldehyde (MDA) and increasing the levels of superoxide dismutase (SOD), catalase (CAT), glutathione peroxidase (GSH-Px), and glutathione reductase (GSH-Rx) [12]. These studies indicated that seafood-derived peptides had strong antioxidant activity and could be served as ingredients in functional food and food systems to protect food quality by reducing oxidative stress.

Hairtail (Trichiurus japonicas) belongs to cutlassfish family of Trichiuridae and is found throughout tropical and temperate waters worldwide. In China, hairtail is one of the four major aquatic products and wildly distributed in the Yellow Sea, the Bo Hai Sea, and the East China Sea. In our previous research, hairtail hydrolysates chelation with iron (Fe-FPH chelate) had higher hemoglobin regeneration efficiency (HRE), longer exhaustive swimming time, and higher SOD activity. 
Additionally, Fe-FPH chelate was found to significantly decrease levels the MDA content, visibly enhance the GSH-Px activity in liver and reduce blood lactic acid of rats [22,23]. Therefore, the aim of this work was to (i) optimize the two-step sequential enzymolysis technology; (ii) isolate and identify the antioxidant peptides; and (iii) evaluate the activities of isolated peptides form protein hydrolysate of hairtail muscle in vitro.

\section{Results and Discussion}

\subsection{Preparation of Protein Hydrolysate from Hairtail (T. japonicas) Muscle (HTP)}

\subsubsection{Effect of Different Proteases on Protein Hydrolysates from Hairtail (T. japonicas) Muscle (HTP)}

$\mathrm{HO} \bullet$ is a highly reactive radical and can destroy all types of macromolecules such as nucleic acids (mutations), carbohydrates, lipids (lipid peroxidation), proteins and amino acids [24]. DPPH is the traditional and perhaps the most popular standard of the position (g-marker) and intensity of electron paramagnetic resonance (EPR) signals [25]. Therefore, DPPH• and HO• has been widely applied to evaluate the antioxidant ability of compounds to act as free radical scavengers or hydrogen donors $[7,25,26]$.

Chemical treatment, enzymatic hydrolysis, and microbial fermentation of food proteins can be used for bioactive peptides production. However, the enzymatic hydrolysis method is preferred in the food and pharmaceutical industries because the other methods may leave residual organic solvents or toxic chemicals in the final products [7]. Treatment of protein substrate with different proteases will produce several types of protein hydrolysates, which exhibit various extents of antioxidant activities against various antioxidant systems $[7,14]$. Therefore, the specificity of the enzyme used for the proteolysis is one of the most important factors for the production of bioactive peptides.

In the experiment, defatted proteins of hairtail muscle were separately hydrolyzed with alcalase, trypsin, neutrase, pepsin, and papain at designed conditions and the antioxidant capacities of the resulted hydrolysates at the concentration of $6.0 \mathrm{mg}$ protein $/ \mathrm{mL}$ were shown in Figure 1 . The data indicated that $\mathrm{HO} \bullet$ scavenging capacities of the protein hydrolysates were significantly influenced by the type of protease $(p<0.05)$. The DPPH• scavenging activities of alcalase and papain hydrolysates were $53.45 \pm 1.05 \%$ and $47.75 \pm 2.34 \%$, respectively, which were significantly higher than those of trypsin $(37.05 \pm 0.97 \%)$, neutrase $(35.05 \pm 0.97 \%)$, and pepsin $(39.85 \pm 1.28 \%)$ hydrolysates $(p<0.05)$ (Figure 1A). The HO• scavenging activities of neutrase, alcalase, and papain hydrolysates were 50.61 $\pm 1.16 \%, 48.76 \pm 1.64 \%$, and $48.89 \pm 1.58 \%$, respectively, which were significantly higher than those of trypsin $(35.21 \pm 0.67 \%)$ and pepsin $(33.29 \pm 1.01 \%)$ hydrolysates $(p<0.05)$ (Figure 1B). However, there were no significant differences on the $\mathrm{HO} \bullet$ scavenging activities of neutrase, alcalase, and papain hydrolysates at the concentration of $6.0 \mathrm{mg}$ protein $/ \mathrm{mL}(p>0.05)$. In addition, the active sites of papain were lie in basic amino acids, particularly Arg- and Lys-; and the active sites of alcalase were lie in Ala-, Leu-, Val-, Tyr-, Phe-, and Try-. The active sites are significantly different between alcalase and papain, which will help to shorten the hydrolysis time and improve the hydrolysis degree (DH) of protein hydrolysates $[7,27,28]$.

Under the designed conditions, the protein hydrolysate of hairtail (T. japonicas) muscle was prepared using binary-enzymes hydrolysis process (papain + alcalase) and referred to as HTP, and the antioxidant activity of protein hydrolysates was presented in Figure 2. At the concentration of $6.0 \mathrm{mg}$ protein $/ \mathrm{mL}$, DPPH• and HO• scavenging activities of HTP were $60.72 \pm 1.05 \%$ and $58.17 \pm 1.53 \%$, respectively, which was significantly higher than those of the hydrolysates prepared separately using papain and alcalase $(p<0.05)$. Therefore, papain and alcalase were selected for the preparation of protein hydrolysate of hairtail muscle. 

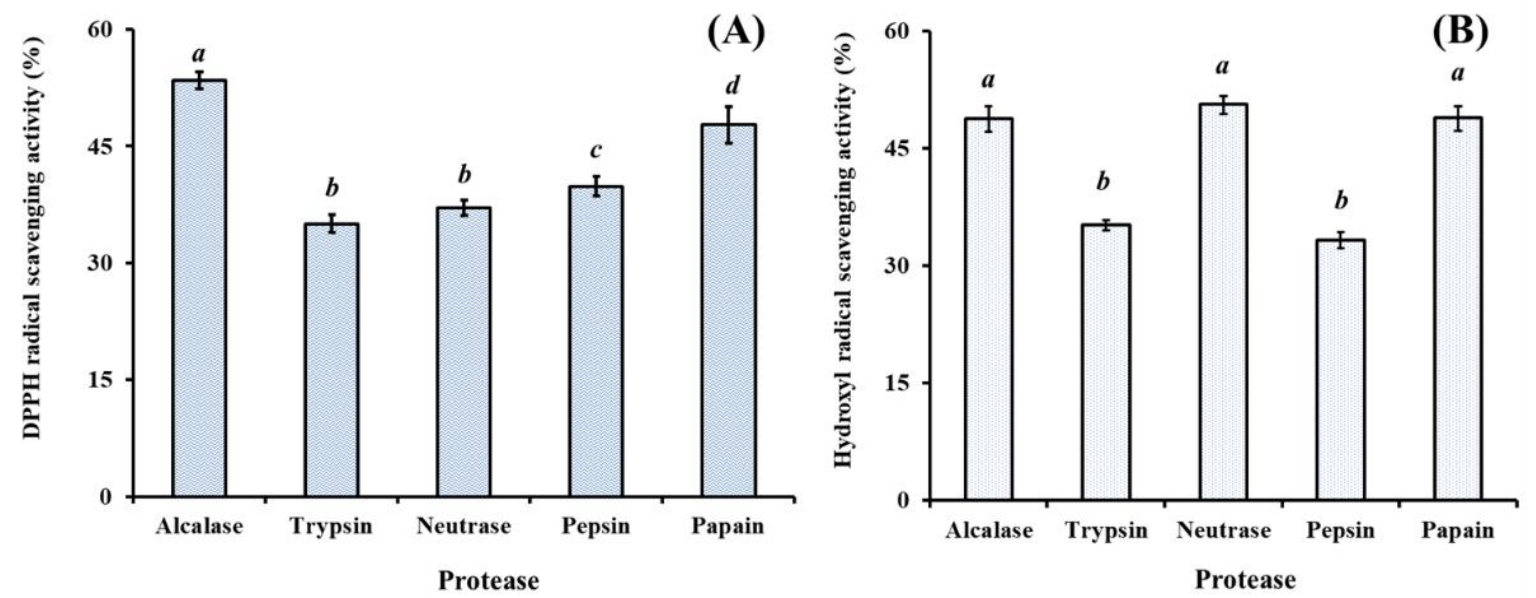

Figure 1. DPPH• (A) and HO• (B) scavenging activities of different enzymatic hydrolysates from hairtail (T. japonicas) muscle at the concentration of $6.0 \mathrm{mg}$ protein $/ \mathrm{mL}$. All data are presented as the mean \pm SD of triplicate results. ${ }^{a-d}$ Values with same letters indicate no significant difference of different sample at same concentrations $(p>0.05)$.

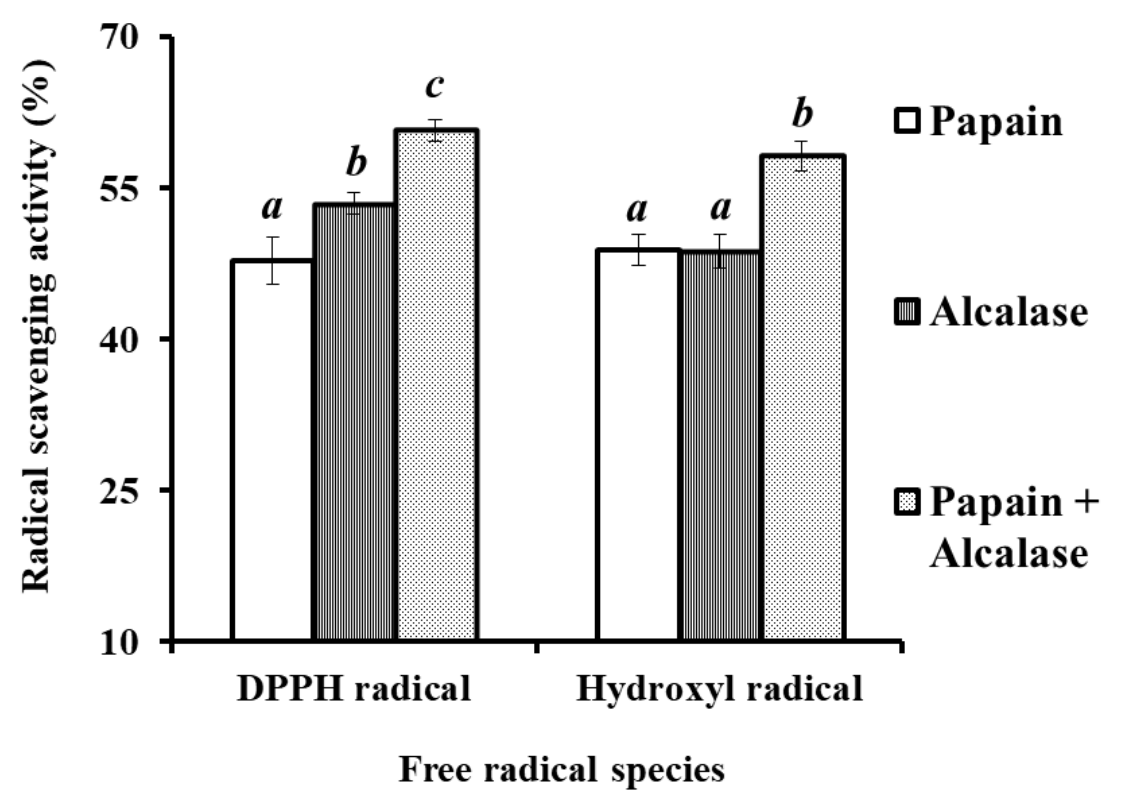

Figure 2. Effect of Papain, Alcalase, and Papain + Alcalase on DPPH• and HO• scavenging activities of protein hydrolysates from hairtail (T. japonicas) muscle at the concentration of $6.0 \mathrm{mg}$ protein $/ \mathrm{mL}$. All data are presented as the mean \pm SD of triplicate results. ${ }^{a-c}$ Values with same letters indicate no significant difference of different sample at same concentrations $(p>0.05)$.

2.2. Purification of Antioxidant Peptides from Protein Hydrolysate from Hairtail (T. japonicas) Muscle (HTP)

\subsubsection{Fractionation of HTP Using Membrane Ultrafiltration}

Membrane ultrafiltration is usually used to enrich the particle sizes of functional molecules and is widely applied in food and beverage processing, biotechnological applications, and pharmaceutical industry [6,7]. Consequently, HTP was divided into four fractions including HTP-I (<1 kDA), HTP-II (1-3 kDa), HTP-III (3-5 kDa), and HTP-IV (>5 kDa) by ultrafiltration with a molecular weight (MW) Cut Off (MWCO) membrane of 1,3, and $5 \mathrm{kDa}$. At the concentration of $6.0 \mathrm{mg}$ protein/mL, DPPH• and HO• scavenging activities of HTP-I were $62.13 \pm 1.97 \%$ and $78.6 \pm 1.74 \%$, respectively, which were significantly stronger than those of HTP, HTP-II, HTP-III, and HTP-IV $(p<0.05)$ (Figure 3$)$. The activities 
of protein hydrolysates and their fractions were affected by the multiple peptides with different chain length and amino acid composition. Sila et al. [7] and Chi et al. [29] reported that MWs of hydrolysates play an important factor in their bioactivities, and hydrolysate fractions with smaller MW showed stronger antioxidant activity than those of larger MW hydrolysates. In the report, HTP-I with short chain peptides showed stronger radical scavenging activity, and this finding was in line with previous reports that the antioxidant abilities of protein hydrolysates were negatively correlated with their average MW $[29,30]$. Therefore, HTP-I was selected for the subsequent chromatographic separation.

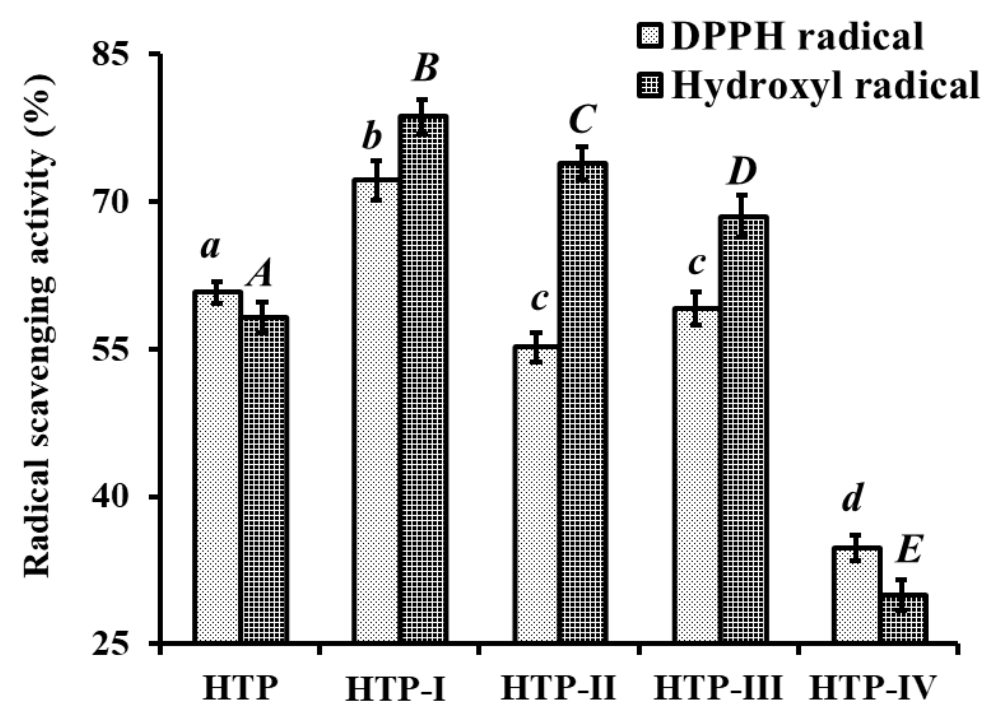

Figure 3. DPPH• and $\mathrm{HO} \bullet$ scavenging activity of HTP and its fractions by membrane ultrafiltration at the concentration of $6.0 \mathrm{mg}$ protein $/ \mathrm{mL}$. All data are presented as the mean $\pm \mathrm{SD}$ of triplicate results. ${ }^{a-c}$ or ${ }^{A-E}$ Column wise values with same superscripts of this type indicate no significant difference $(p>0.05)$.

\subsubsection{Anion-Exchange Chromatography of HTP-I}

Peptides contain acidic and/or hydrophobic amino acid residues such as glutamic acid (Glu), tyrosine (Tyr), methionine (Met), and leucine (Leu), and can be sticks to the anion-exchange resins [31,32]. In addition, acidic and/or hydrophobic amino acid residues in amino acid sequences of peptides will enhance their bioactivities [7,33]. Therefore, anion exchange resins including DEAE-52 cellulose and Q Sepharose FF are usually applied to purified bioactive peptides from protein hydrolysates $[8,34,35]$.

As shown in Figure 4A, five fractions (DE-1 to DE-5) were separated from HTP-I using a DEAE-52 cellulose column. Amongst them, DE-1 and DE-2 were eluted using deionized water, DE-3 was eluted using $0.1 \mathrm{M} \mathrm{NaCl}$, DE-4 was eluted using $0.5 \mathrm{M} \mathrm{NaCl}$, and DE-5 was eluted using $1.0 \mathrm{M} \mathrm{NaCl}$. DPPH• and $\mathrm{HO} \bullet$ scavenging activities of HTP-I and five eluted fractions were showed in Figure 4B, and the results indicated that $\mathrm{DPPH} \bullet(58.91 \pm 1.89 \%)$ and $\mathrm{HO} \bullet(69.74 \pm 2.61 \%)$ scavenging abilities of DE-3 were significantly stronger than those of HTP-I (DPPH•: $40.13 \pm 1.16 \%$; HO•: $45.6 \pm 1.35 \%$ ), DE-1

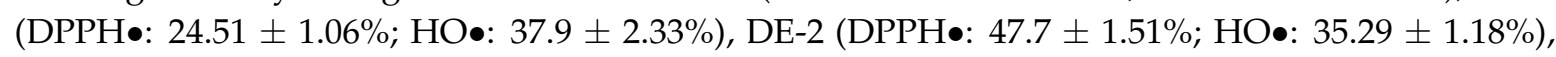

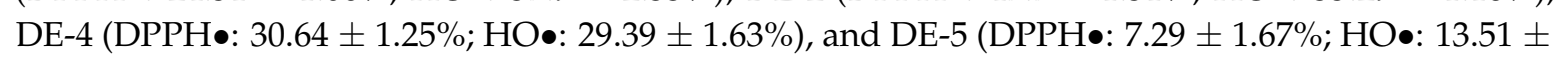
$0.99 \%)$ at the concentration of $5.0 \mathrm{mg}$ protein $/ \mathrm{mL}(p<0.05)$. The results indicated that the highest antioxidant activity of the peptides obtained in DE-3 might be due to the acidic amino acid residues in their peptide sequences. Therefore, DE-3 was selected for the following experiment. 

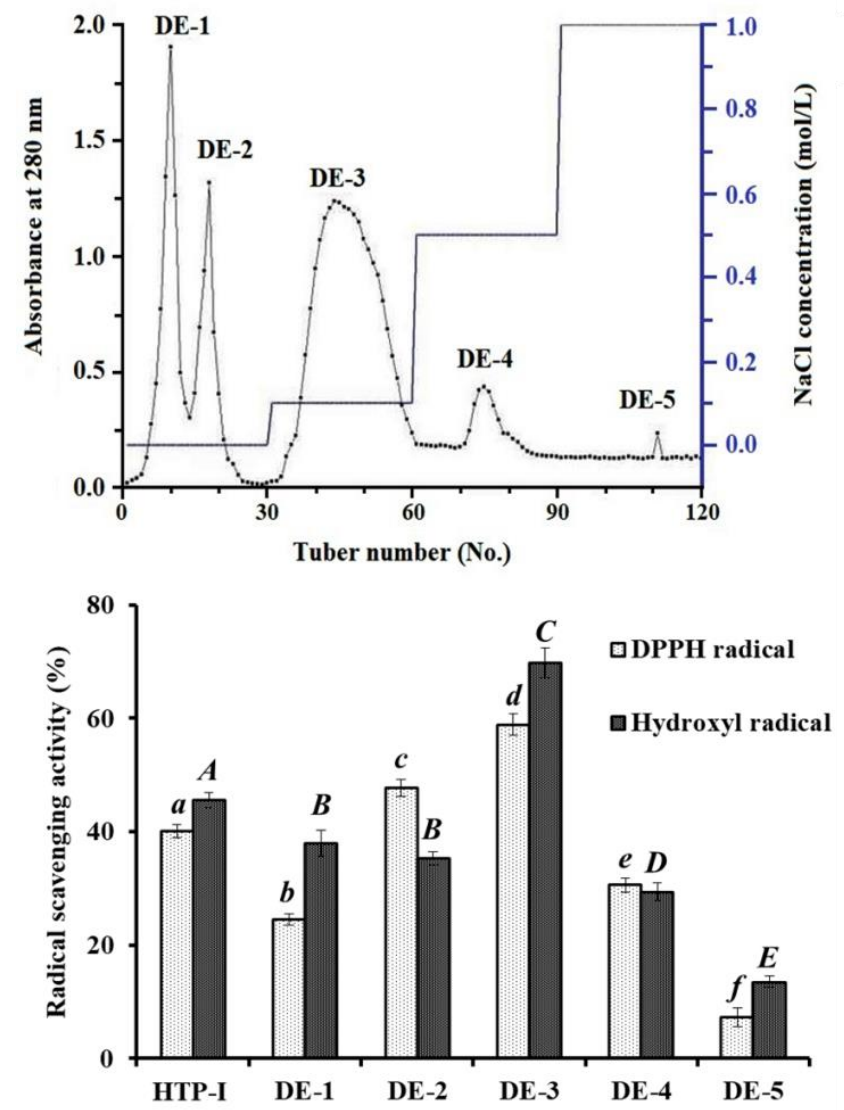

(A)

(B)

Figure 4. Elution profile of HTP-I in DEAE-52 cellulose anion-exchange chromatography (A) and radical scavenging activity of HTP-I and its four subfractions at the concentration of $5.0 \mathrm{mg}$ protein $/ \mathrm{mL}$ (B). All data are presented as the mean $\pm \mathrm{SD}$ of triplicate results. ${ }^{a-f}$ or ${ }^{A-E}$ Values with same superscripts of this type indicate no significant difference $(p>0.05)$.

\subsubsection{Gel Filtration Chromatography (GFC) of DE-3}

GFC is a well-accepted separated technique on the basis of molecular size and usually applied to either fractionate molecules and complexes in a sample into fractions with a particular size range, or remove salt from a preparation of macromolecules $[3,36]$. Therefore, GFC is often used to separate peptides from protein hydrolysates and their fractions $[6,7]$.

As shown in Figure 5A, DE-3 was separated into two fractions of DE-3-1 and DE-3-2 using a Sephadex G-15 column, and each fraction was collected, lyophilized, and then evaluated for DPPH• and $\mathrm{HO} \bullet$ scavenging activity. Figure $5 \mathrm{~B}$ indicated that $\mathrm{DPPH} \bullet$ and $\mathrm{HO} \bullet$ scavenging activities of DE-3-2 were $69.21 \pm 0.91 \%$ and $84.16 \pm 1.26 \%$ at the concentration of $5.0 \mathrm{mg}$ protein $/ \mathrm{mL}$, which were significantly higher than those of DE-3 (DPPH• $58.91 \pm 1.89 \%$; HO• $69.74 \pm 2.61 \%$ ) and DE-3-1 $(\mathrm{DPPH} \bullet 36.27 \pm 0.79 \%$; HO• $41.38 \pm 1.49 \%)(p<0.05)$. Therefore, fraction DE-3-2 was selected for the following isolation process. 

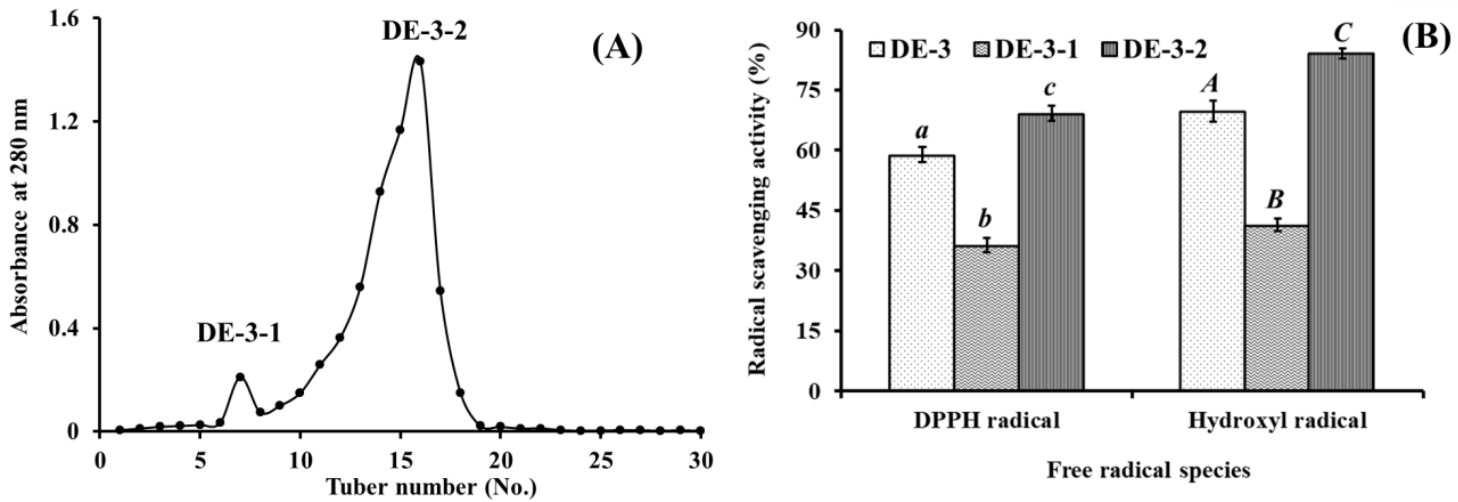

Figure 5. Elution profile of DE-3 in Sephadex G-15 chromatography (A) and radical scavenging activities of DE-3 and its fractions at $5.0 \mathrm{mg}$ protein $/ \mathrm{mL}$ concentration (B). All data are presented as the mean $\pm \mathrm{SD}$ of triplicate results. ${ }^{a-c}$ or ${ }^{A-C}$ Column wise values with same superscripts of this type indicate no significant difference $(p>0.05)$.

2.2.4. Isolation of Peptides from DE-3-2 by Reverse-Phase High Performance Liquid Chromatography (RP-HPLC)

RP-HPLC is an effective technique applied to purify and quantify peptides in a mixture solution on their hydrophobic character [37]. The retention time (RT) can qualitatively analyze the isolated peptide and adjusted by changing the ratio of methanol or acetonitrile in mobile phase, and the peak area can be used for quantitative analysis of the isolated peptide [3,38]. As shown in Figure 6, DE-3-2 was finally purified using RP-HPLC system on an Agilent 1260 HPLC system with a Zorbax C-18 column, and the eluted peptides were gathered separately in accordance with chromatographic peaks. Among all chromatographic fractions, eight peptides with RT of $8.919 \mathrm{~min}$ (TJP1), $9.189 \mathrm{~min}$ (TJP2), $12.112 \mathrm{~min}$ (TJP3), $13.829 \mathrm{~min}$ (TJP4), $14.209 \mathrm{~min}$ (TJP5), $17.237 \mathrm{~min}$ (TJP6), $19.772 \mathrm{~min}$ (TJP7), and $20.436 \mathrm{~min}$ (TJP8) showed high radical scavenging activities. Therefore, TJP1-TJP8 were collected and lyophilized for amino acid sequence identification and activity evaluation.

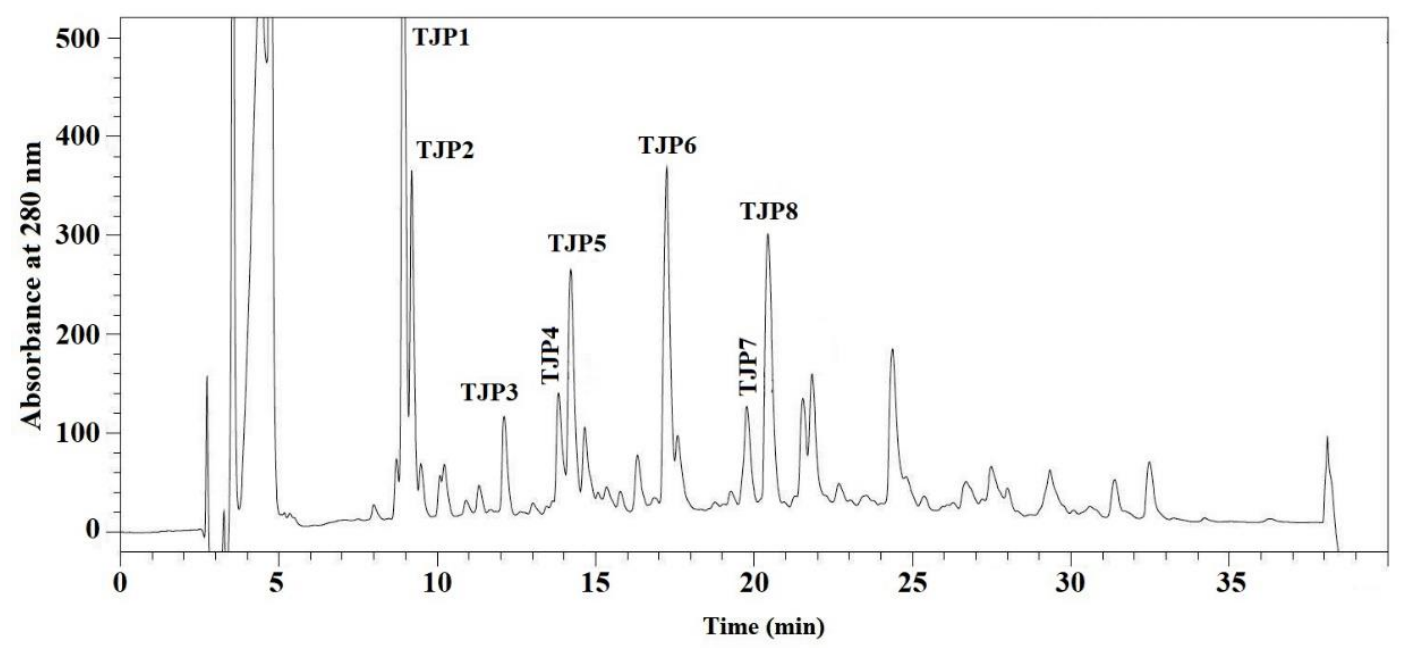

Figure 6. Elution profile of DE-3-2 separated by RP-HPLC system on a Zorbax, SB C-18 column $(4.6 \times$ $250 \mathrm{~mm}$ ) from 0 to $40 \mathrm{~min}$.

\subsection{Amino Acid Sequence Analysis and Mass Spectrometry of Peptides from Protein Hydrolysates of Hairtail Muscle}

For more detailed discussion on the structure-function relationship, the amino acid composition, sequences, and molecular mass of eight isolated peptides (TJP1-TJP8) were determined using protein sequencer and ESI-MS, and the results were shown in Figure 7 and Table 1. The amino acid sequences 
of eight isolated peptides (TJP1-TJP8) were identified as Gln-Asn-Asp-Glu-Arg (TJP1), Lys-Ser (TJP2), Lys-Ala (TJP3), Ala-Lys-Gly (TJP4), Thr-Lys-Ala (TJP5), Val-Lys (TJP6), Met-Lys (TJP7), and Ile-Tyr-Gly (TJP8) with molecular weights of 660.3, 233.0, 217.1, 274.1, 318.0, 245.1, 277.0, and 351.0 Da, respectively, which were agreed well with their theoretical masses of 660.6, 233.3, 217.3, 274.3, 318.4, 245.3, 277.4, and $351.4 \mathrm{Da}$.
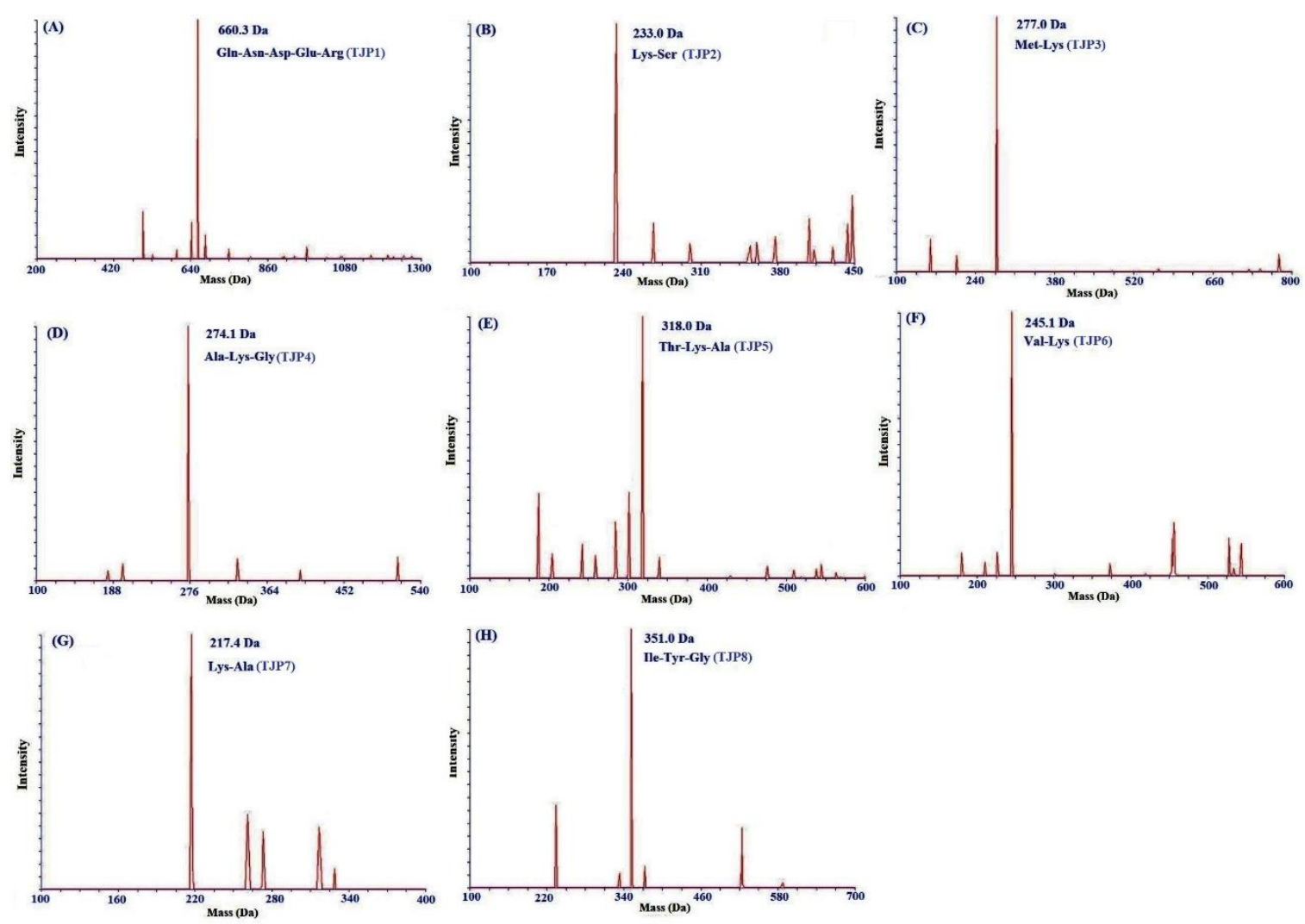

Figure 7. Mass spectra of TJP1 (A), TJP2 (B), TJP3 (C), TJP4 (D), TJP5 (E), TJP6 (F), TJP7 (G), and TJP8 $(\mathrm{H})$ from protein hydrolysate of hairtail (T. japonicas) muscle.

Table 1. Retention time, amino acid sequences, and molecular mass of eight isolated peptides (TJP1 to TJP8) from protein hydrolysate of hairtail (T. japonicas) muscle.

\begin{tabular}{cccc}
\hline & Retention time (min) & Amino acid sequence & Theoretical mass/observed mass (Da) \\
\hline TJP1 & 8.919 & Gln-Asn-Asp-Glu-Arg & $660.3 / 660.6$ \\
TJP2 & 9.189 & Lys-Ser & $233.0 / 233.3$ \\
TJP3 & 12.112 & Lys-Ala & $217.1 / 217.3$ \\
TJP4 & 13.829 & Ala-Lys-Gly & $274.1 / 274.3$ \\
TJP5 & 14.209 & Thr-Lys-Ala & $318.0 / 318.4$ \\
TJP6 & 17.237 & Val-Lys & $245.1 / 245.3$ \\
TJP7 & 19.772 & Met-Lys & $277.0 / 277.4$ \\
TJP8 & 20.436 & Ile-Tyr-Gly & $351.0 / 351.4$ \\
\hline
\end{tabular}

\subsection{Antioxidant Activity}

To better evaluate the antioxidant activity of eight isolated peptides (TJP1 to TJP8) from protein hydrolysate of hairtail (T. japonicas) muscle, four kinds of radical (DPPH•, $\mathrm{HO} \bullet, \mathrm{O}_{2}^{-} \bullet$, and $\mathrm{ABTS}^{+} \bullet$ ) scavenging assays, reducing power, and lipid peroxidation inhibition assay were tested, and the results were presented in Table 2 and Figures 8-10. 
Table 2. Radical scavenging activity of eight isolated peptides (TJP1 to TJP8) from protein hydrolysate of hairtail (T. japonicas) muscle.

\begin{tabular}{ccccc}
\hline & \multicolumn{3}{c}{ EC $_{\text {50 }}(\mathbf{m g} / \mathbf{m L})$} \\
\cline { 2 - 5 } & DPPH• & HO• & $\mathbf{O}_{2}^{-} \bullet$ & ABTS $^{+} \bullet$ \\
\hline TJP1 & 4.95 & 6.865 & 2.753 & 1.925 \\
TJP2 & 7.68 & 5.634 & 4.296 & 2.496 \\
TJP3 & 0.902 & 1.740 & 2.082 & 1.652 \\
TJP4 & 0.626 & 2.378 & 2.538 & 0.831 \\
TJP5 & 1.425 & 5.261 & 4.911 & 3.527 \\
TJP6 & 1.262 & 3.845 & $>10.000$ & 2.835 \\
TJP7 & 3.150 & 4.993 & 4.427 & 8.752 \\
TJP8 & 0.663 & 2.498 & 1.835 & 0.586 \\
Glutathione (GSH) & 0.251 & 0.758 & 0.456 & 0.078 \\
\hline
\end{tabular}
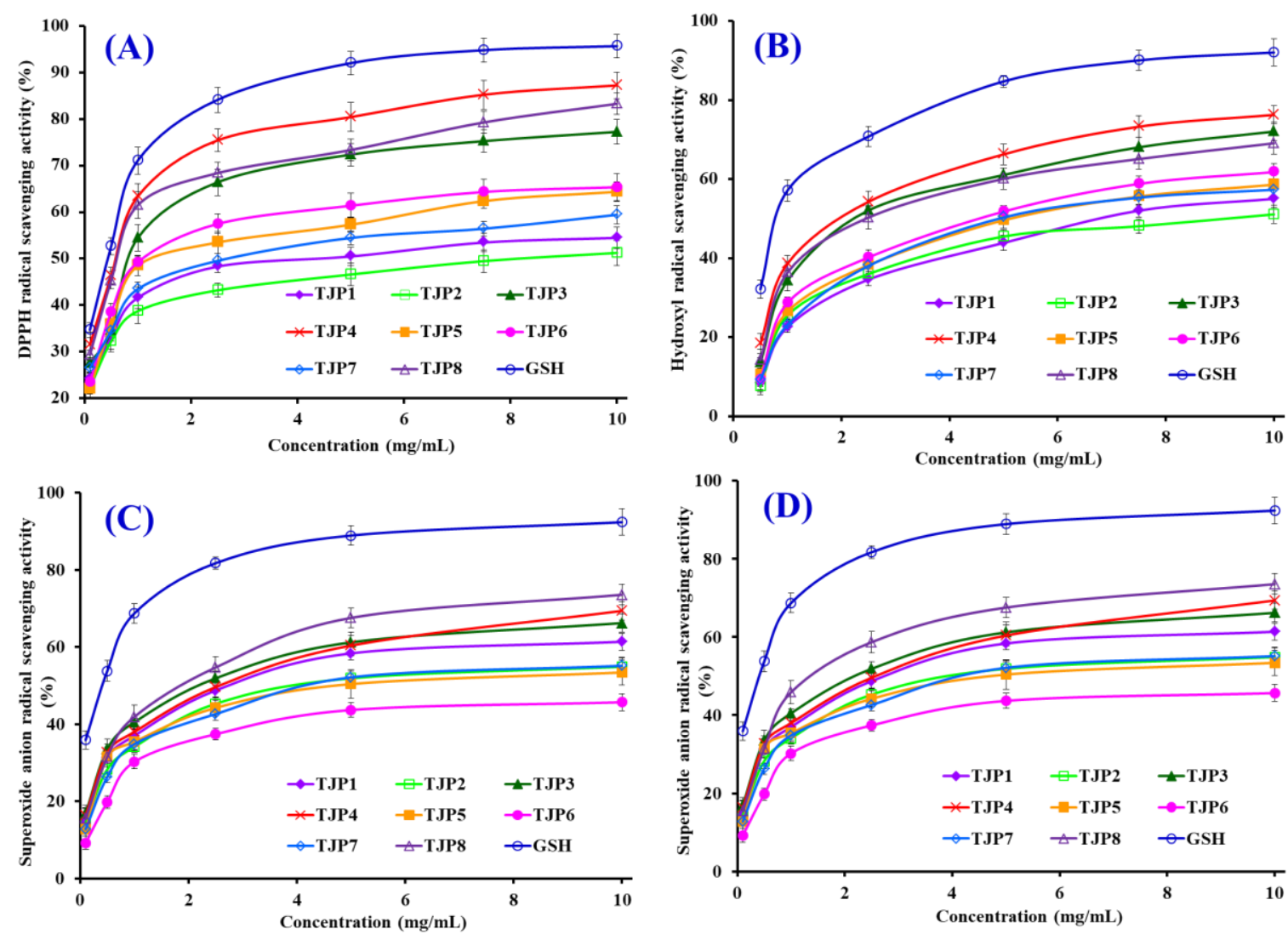

Figure 8. $\mathrm{DPPH} \bullet(\mathbf{A}) ; \mathrm{HO} \bullet(\mathbf{B}) ; \mathrm{O}_{2}^{-} \bullet(\mathbf{C})$; and $\mathrm{ABTS}^{+} \bullet(\mathbf{D})$ scavenging activities of eight isolated peptides (TJP1 to TJP8) from protein hydrolysate of hairtail (T. japonicas) muscle. All data are presented as the mean $\pm \mathrm{SD}$ of triplicate results. 


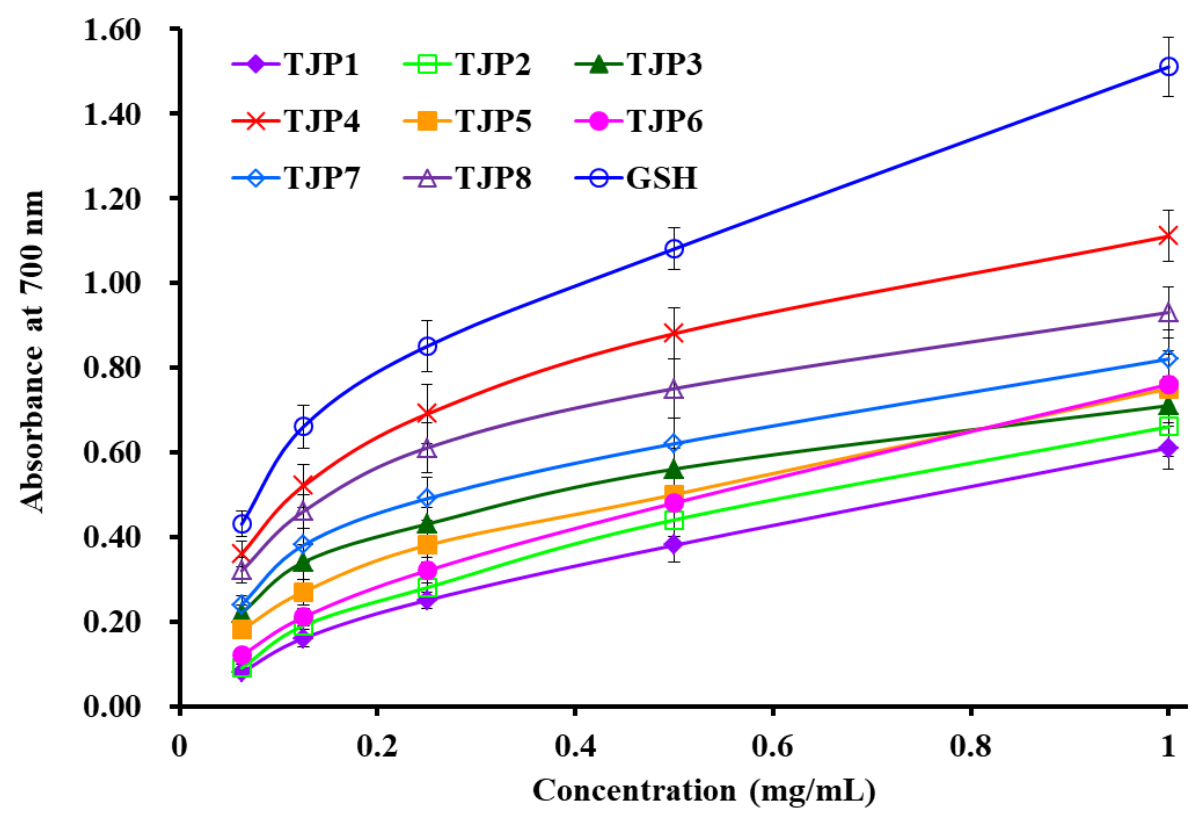

Figure 9. Reducing power of eight isolated peptides (TJP1 to TJP8) from protein hydrolysate of hairtail (T. japonicas) muscle. All data are presented as the mean \pm SD of triplicate results.

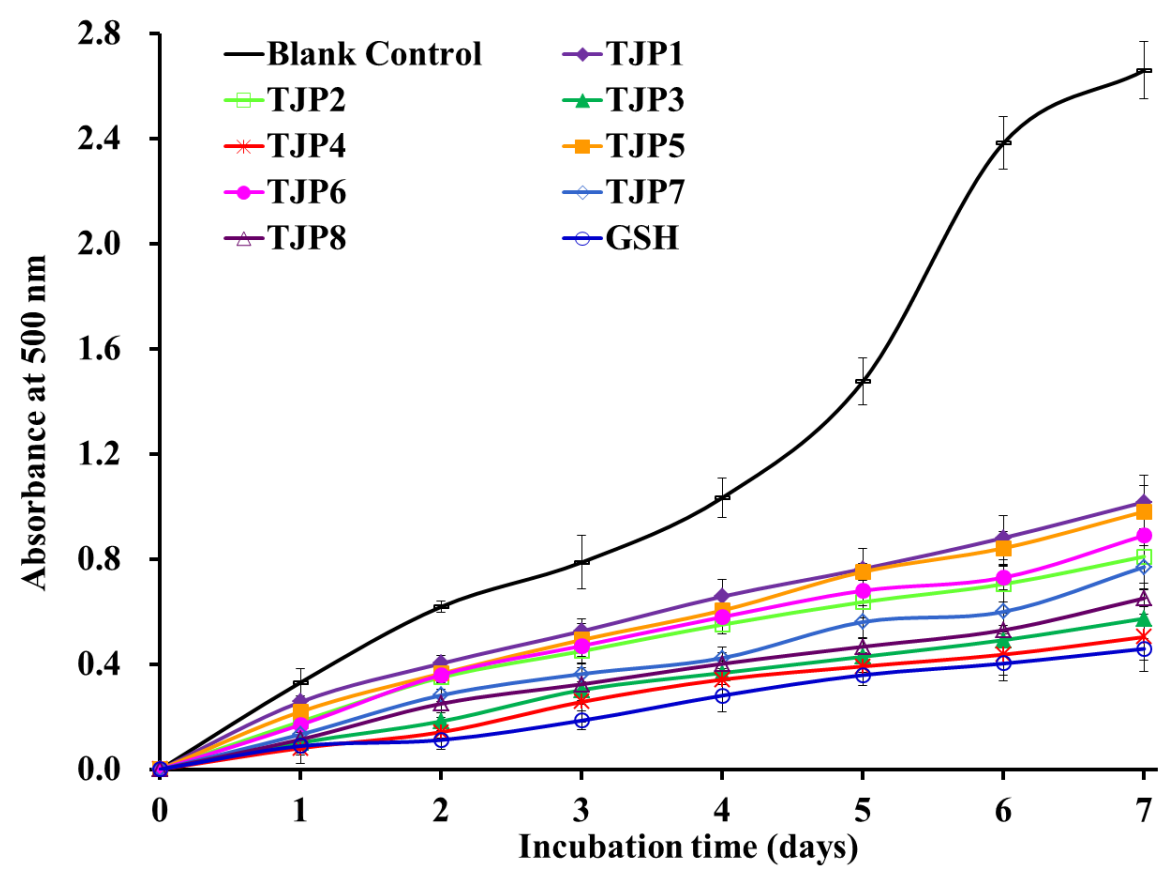

Figure 10. Lipid peroxidation inhibition assays of eight isolated peptides (TJP1 to TJP8) from protein hydrolysate of hairtail (T. japonicas) muscle. All data are presented as the mean $\pm \mathrm{SD}$ of triplicate results.

\subsubsection{Radical Scavenging Activity}

\section{$\mathrm{DPPH} \bullet$ Scavenging Activity}

$\mathrm{DPPH} \bullet$ shows maximal absorbance at $517 \mathrm{~nm}$ in its oxidized form, and the absorbance wears off with the free radical accepting an electron [3]. As shown in Figure 8A, eight isolated peptides (TJP1 to TJP8) showed strong DPPH• scavenging activities and there was also a positive correlation between the concentration and the radical-scavenging activity. The half elimination ratio $\left(\mathrm{EC}_{50}\right)$ values of TJP3, TJP4, and TJP8 were $0.902,0.626$, and $0.663 \mathrm{mg} / \mathrm{mL}$, respectively, and TJP4 exhibited the highest 
DPPH• scavenging ability among eight isolated peptides, but its activity was still lower than that of the positive control of glutathione (GSH) at the same concentration. The $\mathrm{EC}_{50}$ value of TJP4 was lower than those of most antioxidant peptides from protein hydrolysates of loach (PSYV: $17.0 \mathrm{mg} / \mathrm{mL}$ ) [39], miiuy croaker (GIEWA: $0.78 \mathrm{mg} / \mathrm{mL}$ ) [6], scalloped hammerhead cartilage (GPE: $2.43 \mathrm{mg} / \mathrm{mL}$; GARGPQ: $2.66 \mathrm{mg} / \mathrm{mL}$; GFTGPPGFNG: $1.99 \mathrm{mg} / \mathrm{mL}$ ) [12], blue mussel (YPPAK: $2.62 \mathrm{mg} / \mathrm{mL}$ ) [26], bluefin leatherjacket (GPP: $1.927 \mathrm{mg} / \mathrm{mL}$; WEGPK: $4.438 \mathrm{mg} / \mathrm{mL}$; GVPLT: $4.541 \mathrm{mg} / \mathrm{mL}$ ) [8,14], skate cartilages (FIMGPY: $2.60 \mathrm{mg} / \mathrm{mL}$; GPAGDY: $3.48 \mathrm{mg} / \mathrm{mL}$; IVAGPQ: $3.93 \mathrm{mg} / \mathrm{mL}$ ) [24], grass carp skin (GFGPL: $2.249 \mathrm{mg} / \mathrm{mL}$; VGGRP: $2.937 \mathrm{mg} / \mathrm{mL}$ ) [40], and salmon pectoral fin (TTANIEDRR: $2.503 \mathrm{mg} / \mathrm{mL}$ ) [41]. However, the $\mathrm{EC}_{50}$ value of TJP4 was higher than those of peptides from protein hydrolysates of Chinese leek (GSQ: $0.61 \mathrm{mg} / \mathrm{mL}$ ) [42], miiuy croaker (FPYLRH: $0.51 \mathrm{mg} / \mathrm{mL}$ ) [6], grass carp skin (HFGBPFH: $0.20 \mathrm{mg} / \mathrm{mL}$ ) [40], and skate muscle (APPTAYAQS: $0.614 \mathrm{mg} / \mathrm{mL}$; NWDMEKIWD $0.289 \mathrm{mg} / \mathrm{mL}$ ) [10]. Therefore, these data indicated that eight isolated peptides (TJP1 to TJP8), especially TJP3, TJP4, and TJP8 had the strong capacity to contribute an electron or hydrogen radical for suppressing the DPPH• reaction.

\section{HO• Scavenging Activity}

$\mathrm{HO} \bullet$ is a highly reactive radical to the organism and only can be eliminated by endogenous and dietary antioxidants. Therefore, it is the ideal assay for searching the radical scavenging agent of organism. The abilities of eight isolated peptides (TJP1 to TJP8) were investigated, and the dose-related effects were observed at different peptide concentrations ranging from 0 to $10.0 \mathrm{mg} / \mathrm{mL}$ (Figure 8B). $\mathrm{EC}_{50}$ values of TJP3, TJP4, and TJP8 were $1.740,2.378$, and $2.498 \mathrm{mg} / \mathrm{mL}$, respectively, and TJP3 exhibited the highest $\mathrm{HO} \bullet$ scavenging ability among all isolated peptides at the same concentration. $\mathrm{EC}_{50}$ value of TJP3 was lower than those of peptides from protein hydrolysates of bluefin leatherjacket heads (WEGPK: $5.567 \mathrm{mg} / \mathrm{mL}$; GPP: $2.385 \mathrm{mg} / \mathrm{mL}$; GVPLT: $4.149 \mathrm{mg} / \mathrm{mL}$ ) [8], weatherfish loach (PSYV: $2.64 \mathrm{mg} / \mathrm{mL}$ ) [39], skate cartilages (FIMGPY: $3.04 \mathrm{mg} / \mathrm{mL}$; GPAGDY: $3.92 \mathrm{mg} / \mathrm{mL}$; IVAGPQ: $5.03 \mathrm{mg} / \mathrm{mL}$ ) [24], and grass carp skin (PYSFK: 2.283mg/mL; VGGRP: $2.055 \mathrm{mg} / \mathrm{mL}$ ) [40]. However, the $\mathrm{EC}_{50}$ value of TJP3 was higher than those of antioxidant peptides from protein hydrolysates of miiuy croaker (FPYLRH: $0.68 \mathrm{mg} / \mathrm{mL}$; GIEWA: $0.71 \mathrm{mg} / \mathrm{mL}$ ) [6], spotless smoothhound cartilage (GAERP: $0.25 \mathrm{mg} / \mathrm{mL}$; GEREANVM: $0.34 \mathrm{mg} / \mathrm{mL}$; AEVG: $0.06 \mathrm{mg} / \mathrm{mL}$ ) [3], blue mussel (YPPAK: $0.228 \mathrm{mg} / \mathrm{mL}$ ) [26], giant squid (NGLEGLK: $0.313 \mathrm{mg} / \mathrm{mL}$; NADFGLNGLEGLA: $0.612 \mathrm{mg} / \mathrm{mL}$ ) [43], conger eel (LGLNGDDVN: $0.687 \mathrm{mg} / \mathrm{mL}$ ) [44], and skate muscle (APPTAYAQS: $0.390 \mathrm{mg} / \mathrm{mL}$; NWDMEKIWD $0.176 \mathrm{mg} / \mathrm{mL}$ ) [10]. TJP3, TJP4, and TJP8 showed strong HO• scavenging ability, which indicated that it could serve as a $\mathrm{HO} \bullet$ scavenger for decreasing or eliminating the damage caused by $\mathrm{HO} \bullet$ in food industries and biological systems.

\section{$\mathrm{O}_{2}^{-} \bullet$ Scavenging Assay}

$\mathrm{O}_{2}^{-} \bullet$ is the most common free radical generated in vivo, and can promote oxidative reaction to generate peroxy and hydroxyl radicals. Superoxide dismutase protects the cell from the deleterious effects of superoxides in living organisms. Therefore, it is important to search safe and efficient antioxidants for scavenging $\mathrm{O}_{2}^{-} \bullet$. Figure $8 \mathrm{C}$ indicated the $\mathrm{O}_{2}^{-} \bullet$ scavenging ratios of eight isolated peptides (TJP1 to TJP8) drastically increased with increasing concentration ranging from 0.1 to $10 \mathrm{mg} / \mathrm{mL}$, but their activities were still lower than that of glutathione (GSH) at the same concentration. $\mathrm{EC}_{50}$ values of TJP3, TJP4, and TJP8 were 2.082, 2.538, and $1.355 \mathrm{mg} / \mathrm{mL}$, respectively. Therefore, TJP8 played a significant role in $\mathrm{O}_{2}^{-} \bullet$ scavenging. $\mathrm{EC}_{50}$ value of TJP8 was lower than those of peptides from protein hydrolysates of miiuy croaker swim bladders (FYKWP:1.92 mg/mL; FTGMD:3.04 mg/mL; YLPYA:3.61 mg/mL; GFYAA:3.03 mg/mL; FSGLR:3.35 mg/mL; VPDDD:4.11 mg/mL) [6], bluefin leatherjacket heads (WEGPK: $3.223 \mathrm{mg} / \mathrm{mL}$; GPP: $4.668 \mathrm{mg} / \mathrm{mL}$; GVPLT: $2.8819 \mathrm{mg} / \mathrm{mL}$ ) [8], and skate cartilage (FIMGPY: $1.61 \mathrm{mg} / \mathrm{mL}$; GPAGDY: $1.66 \mathrm{mg} / \mathrm{mL}$; IVAGPQ: $1.82 \mathrm{mg} / \mathrm{mL}$ ) [24]. However, $\mathrm{EC}_{50}$ value of TJP8 was higher than those of protein hydrolysates of croceine croaker muscle (YLMR: $0.450 \mathrm{mg} / \mathrm{mL}$; VLYEE: $0.693 \mathrm{mg} / \mathrm{mL}$; MILMR: $0.993 \mathrm{mg} / \mathrm{mL}$ ) [32], skate muscle 
(APPTAYAQS: $0.215 \mathrm{mg} / \mathrm{mL}$; NWDMEKIWD $0.132 \mathrm{mg} / \mathrm{mL}$ ) [10], Mytilus coruscus (SLPIGLMIAM: $0.3168 \mathrm{mg} / \mathrm{mL}$ ) [45], miiuy croaker swim bladders (GFEPY: $0.87 \mathrm{mg} / \mathrm{mL}$; FPPYERRQ: $0.68 \mathrm{mg} / \mathrm{mL}$; FPYLRH: $0.34 \mathrm{mg} / \mathrm{mL}$; GIEWA: $0.30 \mathrm{mg} / \mathrm{mL}$ ) [6], round scad (HDHPVC: $0.265 \mathrm{mg} / \mathrm{mL}$; HEKVC: $0.235 \mathrm{mg} / \mathrm{mL}$ ) [46], monkfish muscle (EWPAQ: $0.624 \mathrm{mg} / \mathrm{mL}$; FLHRP: $0.101 \mathrm{mg} / \mathrm{mL}$; LMGQW: $0.042 \mathrm{mg} / \mathrm{mL}$ ) [47], and croceine croaker scales (GFRGTIGLVG: $0.4630 .151 \mathrm{mg} / \mathrm{mL}$; GPAGPAG: $0.099 \mathrm{mg} / \mathrm{mL}$; GFPSG: $0.151 \mathrm{mg} / \mathrm{mL}$ ) [48]. $\mathrm{O}_{2}^{-} \bullet$ is catalyzed into hydrogen peroxide and oxygen by superoxide dismutases (SOD) in organism. Therefore, TJP3, TJP4, and TJP8 can be applied to eliminate $\mathrm{O}_{2}^{-} \bullet$ damage together with SOD in biological systems.

\section{$\mathrm{ABTS}^{+} \bullet$ Scavenging Assay}

The $\mathrm{ABTS}^{+} \bullet$ is reactive towards most antioxidants and the blue $\mathrm{ABTS}^{+} \bullet$ with an absorption maximum of $734 \mathrm{~nm}$ is converted back to its colorless neutral form during this reaction [3]. Therefore, $\mathrm{ABTS}^{+} \bullet$ scavenging assay is one of the most widely assay used to screen anti-radical peptides. As shown in Figure 8D, eight isolated peptides (TJP1 to TJP8) showed strong ABTS $\bullet$ scavenging activities in a dose-effect manner with $\mathrm{EC}_{50}$ values of $1.925,2.496,1.652,0.831,3.527,2.835,8.752$, and $0.586 \mathrm{mg} / \mathrm{mL}$, respectively. TJP4 and TJP8 showed the strongest ABTS $\bullet$ scavenging activity among eight isolated peptides, but still weaker than glutathione (GSH) did at the same concentration. The $\mathrm{EC}_{50}$ values of TJP4 and TJP8 were significantly lower than those of peptides from protein hydrolysates of salmon (FLNEFLHV: $1.548 \mathrm{mg} / \mathrm{mL}$ ) [41], skate cartilages (FIMGPY: $1.04 \mathrm{mg} / \mathrm{mL}$; IVAGPQ: $1.29 \mathrm{mg} / \mathrm{mL}$ ) [24], bluefin leatherjacket heads (WEGPK: $5.407 \mathrm{mg} / \mathrm{mL}$; GPP: $2.472 \mathrm{mg} / \mathrm{mL}$; GVPLT: $3.124 \mathrm{mg} / \mathrm{mL}$ ) [8], and corn gluten meal (FLPF: $1.497 \mathrm{mg} / \mathrm{mL}$; LPF: $1.013 \mathrm{mg} / \mathrm{mL}$; LLPF: $1.031 \mathrm{mg} / \mathrm{mL}$ ) [49]. However, The $\mathrm{EC}_{50}$ values of TJP4 and TJP8 were significantly higher than those of peptides from protein hydrolysates of skate cartilages (GPAGDY: $0.77 \mathrm{mg} / \mathrm{mL}$ ) [24], grass carp skin (GFGPL: $0.328 \mathrm{mg} / \mathrm{mL}$; VGGRP: $0.465 \mathrm{mg} / \mathrm{mL}$ ) [40], scalloped hammerhead cartilage (GPE: $0.24 \mathrm{mg} / \mathrm{mL}$; GARGPQ: $0.18 \mathrm{mg} / \mathrm{mL}$; GFTGPPGFNG: $0.29 \mathrm{mg} / \mathrm{mL}$ ) [12], and Sphyrna lewini muscle (WDR:0.34 mg $/ \mathrm{mL}$; PYFNK: $0.12 \mathrm{mg} / \mathrm{mL}$ ) [33]. These results indicated that eight isolated peptides (TJP1 to TJP8), especially TJP4 and TJP8, have the strong ability to convert $\mathrm{ABTS}^{+} \bullet$ to its colorless neutral form and hold back the radical chain reaction.

\subsubsection{Reducing Power}

The reducing power is an important indicator for evaluating the activities of antioxidant peptides [30]. As shown in Figure 9, eight isolated peptides (TJP1 to TJP8) exhibited dose-dependent reducing power at the concentrations ranged from $0.5 \mathrm{mg} / \mathrm{mL}$ to $10 \mathrm{mg} / \mathrm{mL}$, and TJP4 showed the higher capacity to reduce ferric ions $\left(\mathrm{Fe}^{3+}\right)$ to ferrous ions $\left(\mathrm{Fe}^{2+}\right)$ than other seven antioxidant peptides. However, the reducing power of eight isolated peptides (TJP1 to TJP8) was lower that of the positive control of GPS.

\subsubsection{Lipid Peroxidation Inhibition Assay}

In the experiment, $\mathrm{DPPH} \bullet, \mathrm{HO} \bullet, \mathrm{O}_{2}^{-} \bullet$, and $\mathrm{ABTS}^{+} \bullet$ scavenging assays have been used to assess the antioxidant activities of eight isolated peptides (TJP1 to TJP8), but oxidative process in biological systems or food products is complicated and embroiled in different kinds of reactions for propagation of lipid radicals and lipid hydroperoxides in the presence of oxygen [3,37]. The radical scavenging assays only measured an antioxidant property, which cannot reflect its role as an antioxidant to protect organism and/or food systems from lipid oxidation [3,32]. As a consequence, we investigated the abilities of eight isolated peptides (TJP1 to TJP8) to control lipid peroxidation in a linoleic acid model system, and the result was presented in Figure 10. The absorbance at $500 \mathrm{~nm}$ of sample solutions with eight isolated peptides (TJP1 to TJP8), respectively, was significantly lower than that of the negative control (without antioxidant), and TJP3, TJP4, and TJP8 revealed similar abilities on lipid oxidation inhibition to that of positive control of GSH. The presented results demonstrated that eight isolated peptides (TJP1 to TJP8) could effectively hold back lipid peroxidation in the tested system during seven 
days of incubation. Furthermore, eight isolated peptides (TJP1 to TJP8) were isolated from the food resource of hairtail (T. japonicas) muscl and considered safer than chemical antioxidants. Therefore, we can increase the using dose of isolated peptides (TJP1 to TJP8) to compensate the flaw that their antioxidant activity is lower than that of chemical antioxidants.

\section{Discussion}

At present, hundreds of antioxidant peptides have been isolated from different resources. However, there is still insufficient evidence to elucidate the structure-activity relationship of antioxidant peptides. Generally, molecular size, hydrophobicity, and amino acid composition and sequence are deemed to play key roles in their antioxidant capacities [7,50].

Bioactivities of antioxidant peptides are highly dependent on their molecular size because small antioxidants have the higher possibility to interact with free radicals to prevent the lipid peroxidation $[3,33]$. Furthermore, smaller peptides are more likely to pass through the blood-brain barrier to perform their physiological functions in the body and have the high possibility to develop into new drugs $[30,51]$. Therefore, shorter size peptides especially peptides with $2-10$ amino acid residues are deemed to obtain stronger radical scavenging and lipid peroxidation inhibition activities than long-chain peptides [6,7]. In the study, eight isolated peptides (TJP1 to TJP8) from protein hydrolysate of hairtail muscle are dipeptides (TJP2, TJP3, TJP6, and TJP7), tripeptides (TJP4, TJP5, and TJP8), or pentapeptide (TJP1), which help them to contact the target more easily to exert their bioactive properties.

More importantly, amino acids play a critical role in the antioxidant of peptides. Sila and Bougatef reported that hydrophobic amino acids, such as Leu, Ile, Ala, Val, and Met, had high reactivity to hydrophobic PUFAs and exert their significant effects on radical scavenging in lipid-rich foods $[7,33]$. Zhao et al. presented that the Ile and Ala residues contribute to the lipid peroxidation inhibitory and radical-scavenging and activities of GIEWA [6]. Therefore, Ala in the sequence of TJP4 and Ile residues in the sequence of TJP8 should positively influence its antioxidant activity. Dávalos et al. [52] and Xing et al. [53] confirmed that Met residue showed the highest antioxidant activity among all the amino acids because its large hydrophobic group can help peptides to facilitate the contacts with hydrophobic radical species. Wu et al. further reported that Met residue in PMRGGGGYHY might work as a reactive site, where the peptide could scavenge oxidants through the formation of a sulfoxide structure after oxidation to stop free-radical chain reactions [54]. Moreover, aromatic residues of aromatic amino acids-including Phe, Trp, and Ty—can keep radical stable during the scavenging process through contributing protons to electron deficient radicals [38]. Tyr residues could turn free radicals into more stable phenoxy radicals to stop the peroxidizing chain reaction [55]. Therefore, Met residues in the sequences of TJP3 and Tyr residues in the sequences TJP8 should be the important contributors for the antioxidant activity of TJP3 and TJP8.

Polar amino acids is reported to play a critical role in $\mathrm{HO} \bullet$ scavenging and metal ion chelating activities because of their carboxyl and amino groups in the side chains [56,57]. Zhu et al. reported that peptides consisted of Lys, Glu, and Asp were identified to have strong abilities to chelate metal ions as well as scavenge $\mathrm{HO} \bullet$ [57]. Ren et al. have reported that basic peptides had greater capacity to scavenge HO• than acidic or neutral peptides [58]. Hu et al. reported that the presence of basic amino acid of Lys was one of the main reasons for the antioxidant activity of NWDMEKIWD [10]. Gly residue is found to contribute significantly to antioxidant activity since the single hydrogen atom in its side chain can provide a high flexibility to the peptide backbone, serving as proton-donors and neutralizing active free radical species $[59,60]$. Therefore, polar amino acids including Lys and Gly residues could play a critical role in the radical scavenging activities of TJP3, TJP4, and TJP8. 


\section{Experimental Section}

\subsection{Materials}

Hairtail (T. japonicas) muscle was purchased from Fengmao Market in Zhoushan city of China. Bovine serum albumin (BSA), DEAE-52 cellulose and Sephadex G-15 were purchased from Shanghai Source Poly Biological Technology Co., Ltd. (Shanghai, China). Acetonitrile (ACN) of LC grade and trifluoroacetic acid (TFA) were purchased from Thermo Fisher Scientific Co., Ltd. (Shanghai, China). Phosphate buffered saline (PBS, pH 7.2), DPPH, and ABTS were purchased from Sigma Chemicals Co. (USA). QNDER(TJP1), KS(TJP2), KA(TJP3), AKG(TJP4), TKA(TJP5), VK(TJP6), MK(TJP7), and IYG(TJP8) with purity higher than $98 \%$ were synthesized in China Peptides Co. (Suzhou, China). All other reagents were analytical grade and purchased from Sinopharm Chemical Reagent Co., Ltd. (Shanghai, China).

\subsection{Preparation of Protein Hydrolysate from Hairtail (T. japonicas) Muscle}

The hairtail (T. japonicas) muscle was homogenized and blended with isopropanol at a ratio of 1:4 $(\mathrm{w} / \mathrm{v})$ and stand at $30 \pm 2{ }^{\circ} \mathrm{C}$ for $1 \mathrm{~h}$. The supernatant was drained and the residue was defatted using isopropanol at a ratio of $1: 4(\mathrm{w} / \mathrm{v})$ at $75 \pm 2{ }^{\circ} \mathrm{C}$ for $90 \mathrm{~min}$. Finally, the supernatant was then removed and the solid precipitate was air-dried at $35 \pm 2{ }^{\circ} \mathrm{C}$.

The resulted precipitate was dispersed in distilled water (DW) at a ratio of 1:10 (w/v), and hydrolyzed separately using trypsin at $\mathrm{pH} 7.8,37.5^{\circ} \mathrm{C}$, alcalase at $\mathrm{pH} 8.5,50^{\circ} \mathrm{C}$, neutrase at $\mathrm{pH} 7.0$, $50{ }^{\circ} \mathrm{C}$, papain at $\mathrm{pH} 7.0,50{ }^{\circ} \mathrm{C}$ and pepsin at $\mathrm{pH} 2.0,37.5^{\circ} \mathrm{C}$ with total enzyme dose $2 \%(\mathrm{w} / \mathrm{w}, 2 \mathrm{~g}$ enzyme $/ 100 \mathrm{~g}$ defatted precipitate powder). In $4 \mathrm{~h}$, the protein hydrolysates were heated to $95{ }^{\circ} \mathrm{C}$ for $10 \mathrm{~min}$ and centrifuged at 12,000 $\mathrm{g}$ for $15 \mathrm{~min}$, and the five supernatants were lyophilized. Protein hydrolysates prepared separately using alcalase and papain exhibited the highest $\mathrm{HO} \bullet$ scavenging activity among five protein hydrolysates. Therefore, defatted precipitate of hairtail muscle was scattered in DW at a ratio of 1:5 (w/v), and hydrolyzed using papain and alcalase for 5 and $6 \mathrm{~h}$ successively on above hydrolysis conditions. The resulted hydrolysate was treated in the same manner as the above method and referred to as HTP.

The concentrations of protein hydrolysate and its fractions were expressed as $\mathrm{mg}$ protein $/ \mathrm{mL}$ and measured by the dye binding method of Bradford (1976) with BSA as the standard protein.

\subsection{Isolation of Peptides from HTP}

\subsubsection{Fractionation of HTP by Ultrafiltration}

HTP was fractionated using ultrafiltration (8400, Millipore, Hangzhou, China) with 1, 3, and $5 \mathrm{kDa}$ MWCO membranes (Millipore, Hangzhou, China), and four fractions termed HTP-I (MW < $1 \mathrm{kDa}$ ), HTP-II (MW 1-3 kDa), HTP-III (MW 3-5 kDa), and HTP-IV (MW > $5 \mathrm{kDa}$ ) were collected and lyophilized.

\subsubsection{Anion-Exchange Chromatography}

HTP-I solution $(5 \mathrm{~mL}, 40.0 \mathrm{mg} / \mathrm{mL})$ was injected into a DEAE- 52 cellulose column $(1.6 \times 80 \mathrm{~cm})$ pre-equilibrated with DW, and stepwise eluted with $150 \mathrm{ml} \mathrm{DW}, 0.1 \mathrm{M} \mathrm{NaCl}, 0.5 \mathrm{M} \mathrm{NaCl}$, and $1.0 \mathrm{M}$ $\mathrm{NaCl}$ solution at a flow rate of $1.0 \mathrm{~mL} / \mathrm{min}$, respectively. Each eluate $(5 \mathrm{~mL})$ was monitored at $280 \mathrm{~nm}$. Finally, five fractions (DE-1 to DE-5) were pooled and lyophilized on the chromatographic peaks.

\subsubsection{Gel Filtration Chromatography}

DE-3 solution $(5 \mathrm{~mL}, 10.0 \mathrm{mg} / \mathrm{mL})$ was separated on a Sephadex G-15 column $(2.6 \times 160 \mathrm{~cm})$ eluted with DW at a flow rate of $0.6 \mathrm{~mL} / \mathrm{min}$. Each eluate $(3 \mathrm{~mL})$ was collected and monitored at $280 \mathrm{~nm}$, and fraction of DE-3-2 with higher activity than others were collected and lyophilized. 


\subsubsection{RP-HPLC}

DE-3-2 was further purified on an Agilent 1260 HPLC system (Agilent Ltd., Santa Rosa, California, USA) with a Zorbax, SB C-18 column $(4.6 \times 250 \mathrm{~mm})$. The sample was eluated with a linear gradient of acetonitrile (0-50\% in $0-40 \mathrm{~min}$ ) in $0.1 \%$ TFA at a flow rate of $0.8 \mathrm{~mL} / \mathrm{min}$. Eight peptides (TJP1 to TJP8) were isolated on the absorbance at $280 \mathrm{~nm}$ and lyophilized.

\subsection{Determination of Amino Acid Sequence and Molecular Mass}

The amino acid sequences and molecular masses of eight isolated peptides (TJP1 to TJP8) was measured on an Applied Biosystems 494 protein sequencer (Perkin Elmer/Applied Biosystems Inc., Foster City, CA, USA) and a Q-TOF mass spectrometer coupled with an electrospray ionization source (ESI), respectively.

\subsection{Antioxidant Activity}

The DPPH•, $\mathrm{HO} \bullet, \mathrm{O}_{2}^{-} \bullet$, and $\mathrm{ABTS}^{+} \bullet$ scavenging activities of eight isolated peptides (TJP1 to TJP8) were measured on the previous method [52], and the $\mathrm{EC}_{50}$ was defined as the concentration where a sample caused a 50\% decrease of the initial concentration of radical. The reducing power assay of eight isolated peptides (TJP1 to TJP8) was determined by the description of a literature report [30]. The lipid peroxidation inhibition assay of eight isolated peptides (TJP1 to TJP8) were determined in a linoleic acid model system on the method of Wang et al. [33].

\subsection{Statistical Analysis}

The data are reported as the mean \pm standard deviation (SD) with three determinations. A one-way analysis of variance (ANOVA) test for differences between means of each group was applied to analyzed data using SPSS 19.0 (Statistical Program for Social Sciences, SPSS Corporation, Chicago, IL, USA). A p-value of less than 0.05 was considered statistically significant.

\section{Conclusions}

In the experiment, eight isolated peptides (TJP1 to TJP8) from protein hydrolysate of hairtail (T. japonicas) muscle prepared with alcalase + papain were isolated and identified as QNDER (TJP1), KS (TJP2), KA (TJP3), AKG (TJP4), TKA (TJP5), VK (TJP6), MK (TJP7), and IYG (TJP8), respectively, which exhibited high antioxidant activities through radical scavenging, reducing power, and lipid peroxidation inhibition assays. On the present results, the peptide fractions and isolated peptides (TJP1 to TJP8) from protein hydrolysate of hairtail (T. japonicas) muscle may be applied as an ingredient in new functional foods, and detailed studies will be done to illustrate the relationship between the activities and structures of eight isolated peptides. In addition, animal feeding experiments on isolated peptides (TJP1 to TJP8) will be conducted to evaluate their in vivo antioxidant effects.

Author Contributions: B.W. and J.-C.H. conceived and designed the experiments. X.-R.Y., D.-G.D., and L.Z. performed the experiments and analyzed the data. C.-F.C. and B.W. contributed the reagents, materials, and analytical tools and wrote the paper.

Funding: This work was funded by the National Natural Science Foundation of China (NSFC) (no. 81673349), International S\&T Cooperation Program of China (2012DFA30600), Zhejiang Province Public Technology Research Project (LGN18D060002), and Natural Science Foundation of Zhejiang Province of China (LY17C200011).

Acknowledgments: The authors thank Zhao-Hui Li at Beijing agricultural biological testing center for his technical support on the isolation and amino acid sequence identification of peptides from hairtail (T. japonicas) muscle.

Conflicts of Interest: The authors declare no conflict of interest. 


\section{References}

1. Rahman, M.S.; Choi, Y.H.; Choi, Y.S.; Alam, M.B.; Lee, S.H.; Yoo, J.C. A novel antioxidant peptide, purified from Bacillus amyloliquefaciens, showed strong antioxidant potential via Nrf-2 mediated heme oxygenase-1 expression. Food Chem. 2018, 239, 502-510. [CrossRef] [PubMed]

2. Zheng, Z.; Si, D.; Ahmad, B.; Li, Z.; Zhang, R. A novel antioxidative peptide derived from chicken blood corpuscle hydrolysate. Food Res. Int. 2018, 106, 410-419. [CrossRef] [PubMed]

3. Tao, J.; Zhao, Y.Q.; Chi, C.F.; Wang, B. Bioactive peptides from cartilage protein hydrolysate of spotless smoothhound and their antioxidant activity In vitro. Mar. Drugs 2018, 16, 100. [CrossRef] [PubMed]

4. Gogineni, V.; Hamann, M.T. Marine natural product peptides with therapeutic potential: Chemistry, biosynthesis, and pharmacology. BBA-Gen. Subj. 2018, 1862, 81-196. [CrossRef] [PubMed]

5. Carocho, M.; Morales, P.; Ferreira, I.C.F.R. Antioxidants: Reviewing the chemistry, food applications, legislation and role as preservatives. Trends Food Sci. Technol. 2018, 71, 107-120. [CrossRef]

6. Zhao, W.H.; Luo, Q.B.; Pan, X.; Chi, C.F.; Sun, K.L.; Wang, B. Preparation, identification, and activity evaluation of ten antioxidant peptides from protein hydrolysate of swim bladders of miiuy croaker (Miichthys miiuy). J. Funct. Foods 2018, 47, 503-511. [CrossRef]

7. Sila, A.; Bougatef, A. Antioxidant peptides from marine by-products: Isolation, identification and application in food systems. A review. J. Funct. Foods 2016, 21, 10-26. [CrossRef]

8. Chi, C.F.; Wang, B.; Wang, Y.M.; Zhang, B.; Deng, S.G. Isolation and characterization of three antioxidant peptides from protein hydrolysate of bluefin leatherjacket (Navodon septentrionalis) heads. J. Funct. Foods 2015, 12, 1-10. [CrossRef]

9. Cömert, E.D.; Gökmen, V. Evolution of food antioxidants as a core topic of food science for a century. Food Res. Int. 2018, 105, 76-93. [CrossRef]

10. Hu, F.Y.; Chi, C.F.; Wang, B.; Deng, S.G. Two novel antioxidant nonapeptides from protein hydrolysate of skate (Raja porosa). Muscle. Mar. Drugs 2015, 13, 1993-2009. [CrossRef]

11. Shahidi, F.; Janitha, P.K.; Wanasundara, P.D. Phenolic antioxidants. Crit. Rev. Food Sci. 1992, 32, 67-103. [CrossRef] [PubMed]

12. Li, X.R.; Chi, C.F.; Li, L.; Wang, B. Purification and identification of antioxidant peptides from protein hydrolysate of scalloped hammerhead (Sphyrna lewini) cartilage. Mar. Drugs 2017, 15, 61. [CrossRef] [PubMed]

13. Wang, B.; Gong, Y.D.; Li, Z.R.; Yu, D.; Chi, C.F.; Ma, J.Y. Isolation and characterisation of five novel antioxidant peptides from ethanol-soluble proteins hydrolysate of spotless smoothhound (Mustelus griseus) muscle. J. Funct. Foods 2014, 6, 176-185. [CrossRef]

14. Chi, C.F.; Wang, B.; Hu, F.Y.; Wang, Y.M.; Zhang, B.; Deng, S.G.; Wu, C.W. Purification and identification of three novel antioxidant peptides from protein hydrolysate of bluefin leatherjacket (Navodon septentrionalis) skin. Food Res. Int. 2015, 73, 124-139. [CrossRef]

15. Lassoued, I.; Mora, L.; Nasri, R.; Jridi, M.; Toldrá, F.; Aristoy, M.C.; Barkia, A.; Nasri, M. Characterization and comparative assessment of antioxidant and ACE inhibitory activities of thornback ray gelatin hydrolysates. J. Funct. Foods 2015, 13, 225-238. [CrossRef]

16. Harnedy, P.A.; O'Keeffe, M.B.; FitzGerald, R.J. Fractionation and identification of antioxidant peptides from an enzymatically hydrolysed Palmaria palmata protein isolate. Food Res. Int. 2017, 100 (Pt 1), 416-422. [CrossRef]

17. Silva, J.F.X.; Ribeiro, K.; Silva, J.F.; Cahú, T.B.; Bezerra, R.S. Utilization of tilapia processing waste for the production of fish protein hydrolysate. Anim. Feed Sci. Technol. 2014, 196, 96-106. [CrossRef]

18. Ma, Y.; Wu, Y.; Li, L. Relationship between primary structure or spatial conformation and functional activity of antioxidant peptides from Pinctada fucata. Food Chem. 2018, 264, 108-117. [CrossRef]

19. Ahn, C.B.; Kim, J.G.; Je, J.Y. Purification and antioxidant properties of octapeptide from salmon byproduct protein hydrolysate by gastrointestinal digestion. Food Chem. 2014, 147, 78-83. [CrossRef]

20. Zhang, Q.; Song, C.; Zhao, J.; Shi, X.; Sun, M.; Liu, J.; Fu, Y.; Jin, W.; Zhu, B. Separation and characterization of antioxidative and angiotensin converting enzyme inhibitory peptide from jellyfish gonad hydrolysate. Molecules 2018, 23, E94. [CrossRef]

21. Jin, J.E.; Ahn, C.B.; Je, J.Y. Purification and characterization of antioxidant peptides from enzymatically hydrolyzed ark shell (Scapharca subcrenata). Process Biochem. 2018, 72, 170-176. [CrossRef] 
22. Huang, S.; Lin, H.; Deng, S.G. Study of anti-fatigue effect in rats of ferrous chelates including hairtail protein hydrolysates. Nutrients 2015, 7, 9860-9871. [CrossRef]

23. Lin, H.M.; Deng, S.G.; Huang, S.B.; Li, Y.J.; Song, R. The effect of ferrous-chelating hairtail peptides on iron deficiency and intestinal flora in rats. J. Sci. Food Agric. 2016, 96, 2839-2844. [CrossRef] [PubMed]

24. Pan, X.; Zhao, Y.Q.; Hu, F.Y.; Wang, B. Preparation and identification of antioxidant peptides from protein hydrolysate of skate (Raja porosa) cartilage. J. Funct. Foods 2016, 25, 220-230. [CrossRef]

25. Hamlaoui, I.; Bencheraiet, R.; Bensegueni, R.; Bencharif, M. Experimental and theoretical study on DPPH radical scavenging mechanism of some chalcone quinoline derivatives. J. Mol. Struct. 2018, 1156, 385-389. [CrossRef]

26. Wang, B.; Li, L.; Chi, C.F.; Ma, J.H.; Luo, H.Y.; Xu, Y.F. Purification and characterisation of a novel antioxidant peptide derived from blue mussel (Mytilus edulis) protein hydrolysate. Food Chem. 2013, 138, 1713-1719. [CrossRef] [PubMed]

27. Bougatef, A.; Balti, R.; Haddar, A.; Jellouli, K.; Souissi, N.; Nasri, M. Antioxidant and functional properties of protein hydrolysates of bluefin tuna (Thunnus thynnus) heads as influenced by the extent of enzymatic hydrolysis. Biotechnol. Bioprocess Eng. 2012, 17, 841-852. [CrossRef]

28. Luo, H.Y.; Wang, B.; Li, Z.R.; Chi, C.F.; Zhang, Q.H.; He, G.Y. Preparation and evaluation of antioxidant peptide from papain hydrolysate of Sphyrna lewini muscle protein. LWT-Food Sci. Technol. 2013, 51, 281-288. [CrossRef]

29. Chi, C.F.; Cao, Z.H.; Wang, B.; Hu, F.Y.; Li, Z.R.; Zhang, B. Antioxidant and functional properties of collagen hydrolysates from spanish mackerel skin as influenced by average molecular weight. Molecules 2014, 19, 11211-11230. [CrossRef] [PubMed]

30. Li, Z.; Wang, B.; Chi, C.; Gong, Y.; Luo, H.; Ding, G. Influence of average molecular weight on antioxidant and functional properties of cartilage collagen hydrolysates from Sphyrna lewini, Dasyatis akjei and Raja porosa. Food Res. Int. 2013, 51, 283-293. [CrossRef]

31. Chi, C.F.; Hu, F.Y.; Wang, B.; Li, Z.R.; Luo, H.Y. Influence of amino acid compositions and peptide profiles on antioxidant capacities of two protein hydrolysates from skipjack tuna (Katsuwonus pelamis) dark muscle. Mar. Drugs 2015, 13, 2580-2601. [CrossRef] [PubMed]

32. Chi, C.F.; Hu, F.Y.; Wang, B.; Ren, X.J.; Deng, S.G.; Wu, C.W. Purification and characterization of three antioxidant peptides from protein hydrolyzate of croceine croaker (Pseudosciaena crocea) muscle. Food Chem. 2015, 168, 662-667. [CrossRef] [PubMed]

33. Wang, B.; Li, Z.R.; Chi, C.F.; Zhang, Q.H.; Luo, H.Y. Preparation and evaluation of antioxidant peptides from ethanol-soluble proteins hydrolysate of Sphyrna lewini muscle. Peptides 2012, 36, 240-250. [CrossRef] [PubMed]

34. Wiriyaphan, C.; Chitsomboon, B.; Yongsawadigul, J. Antioxidant activity of protein hydrolysates derived from threadfin bream surimi byproducts. Food Chem. 2012, 132, 104-111. [CrossRef]

35. Sudhakar, S.; Nazeer, R.A. Preparation of potent antioxidant peptide from edible part of shortclub cuttlefish against radical mediated lipid and DNA damage. LWT_Food Sci. Technol. 2015, 64, 593-601. [CrossRef]

36. Lafarga, T.; Hayes, M. Bioactive peptides from meat muscle and by-products: Generation, functionality and application as functional ingredients. Meat Sci. 2014, 98, 227-239. [CrossRef]

37. Agrawal, H.; Joshi, R.; Gupta, M. Isolation, purification and characterization of antioxidative peptide of pearl millet (Pennisetum glaucum) protein hydrolysate. Food Chem. 2016, 204, 365-372. [CrossRef] [PubMed]

38. Orsini Delgado, M.C.; Nardo, A.; Pavlovic, M.; Rogniaux, H.; Añón, M.C.; Tironi, V.A. Identification and characterization of antioxidant peptides obtained by gastrointestinal digestion of amaranth proteins. Food Chem. 2016, 197, 1160-1167. [CrossRef]

39. You, L.; Zhao, M.; Regenstein, J.M.; Ren, J. Purification and identification of antioxidative peptides from loach (Misgurnus anguillicaudatus) protein hydrolysate by consecutive chromatography and electrospray ionizationmass spectrometry. Food Res. Int. 2010, 43, 1167-1173. [CrossRef]

40. Cai, L.; Wu, X.; Zhang, Y.; Li, X.; Ma, S.; Li, J. Purification and characterization of three antioxidant peptides from protein hydrolysate of grass carp (Ctenopharyngodon idella) skin. J. Funct. Foods 2015, 16, 234-242. [CrossRef]

41. Ahn, C.B.; Cho, Y.S.; Je, J.Y. Purification and anti-inflammatory action of tripeptide from salmon pectoral fin byproduct protein hydrolysate. Food Chem. 2015, 168, 151-156. [CrossRef] [PubMed] 
42. Hong, J.; Chen, T.T.; Hu, P.; Yang, J.; Wang, S.Y. Purification and characterization of an antioxidant peptide (GSQ) from Chinese leek (Allium tuberosum Rottler) seeds. J. Funct. Foods 2014, 10, 1-10. [CrossRef]

43. Rajapakse, N.; Mendis, E.; Byun, H.G.; Kim, S.K. Purification and in vitro antioxidative effects of giant squid muscle peptides on free radical-mediated oxidative systems. J. Nutr. Biochem. 2005, 9, 562-569. [CrossRef] [PubMed]

44. Ranathunga, S.; Rajapakse, N.; Kim, S.K. Purification and characterization of antioxidantative peptide derived from muscle of conger eel (Conger myriaster). Eur. Food Res. Technol. 2006, 222, 310-315. [CrossRef]

45. Kim, E.K.; Oh, H.J.; Kim, Y.S.; Hwang, J.W.; Ahn, C.B.; Lee, J.S.; Jeon, Y.J.; Moon, S.H.; Sung, S.H.; Jeon, B.T.; et al. Purification of a novel peptide derived from Mytilus coruscus and in vitro/in vivo evaluation of its bioactive properties. Fish Shellfish Immunol. 2013, 34, 1078-1084. [CrossRef] [PubMed]

46. Jiang, H.; Tong, T.; Sun, J.; Xu, Y.; Zhao, Z.; Liao, D. Purification and characterization of antioxidative peptides from round scad (Decapterus maruadsi) muscle protein hydrolysate. Food Chem. 2014, 154, 158-163. [CrossRef] [PubMed]

47. Chi, C.F.; Wang, B.; Wang, Y.M.; Deng, S.G.; Ma, J.H. Isolation and characterization of three antioxidant pentapeptides from protein hydrolysate of monkfish (Lophius litulon) muscle. Food Res. Int. 2014, 55, 222-228. [CrossRef]

48. Wang, B.; Wang, Y.; Chi, C.; Hu, F.; Deng, S.; Ma, J. Isolation and characterization of collagen and antioxidant collagen peptides from scales of croceine croaker (Pseudosciaena crocea). Mar. Drugs 2013, 11, 4641-4661. [CrossRef] [PubMed]

49. Zhuang, H.; Tang, N.; Yuan, Y. Purification and identification of antioxidant peptides from corn gluten meal. J. Funct. Foods 2013, 5, 1810-1821. [CrossRef]

50. Agyei, D.; Ongkudon, C.M.; Wei, C.Y.; Chan, A.S.; Danquah, M.K. Bioprocess challenges to the isolation and purification of bioactive peptides. Food Bioprod. Process. 2016, 98, 244-256. [CrossRef]

51. Deane, R.; Du Yan, S.; Submamaryan, R.K.; LaRue, B.; Jovanovic, S.; Hogg, E.; Welch, D.; Manness, L.; Lin, C.; $\mathrm{Yu}$, J.; et al. RAGE mediates amyloid-beta peptide transport across the blood-brain barrier and accumulation in brain. Nat. Med. 2003, 9, 907-913. [CrossRef] [PubMed]

52. Dávalos, A.; Miguel, M.; Bartolomé, B.; López-Fandiño, R. Antioxidant activity of peptides derived from egg white proteins by enzymatic hydrolysis. J. Food Protect. 2004, 67, 1939-1944. [CrossRef]

53. Xing, L.; Hu, Y.; Hu, H.; Ge, Q.; Zhou, G.; Zhang, W. Purification and identification of antioxidative peptides from dry-cured Xuanwei ham. Food Chem. 2016, 194, 951-958. [CrossRef] [PubMed]

54. Wu, R.; Wu, C.; Liu, D.; Yang, X.; Huang, J.; Zhang, J.; Liao, B.; He, H. Antioxidant and anti-freezing peptides from salmon collagen hydrolysate prepared by bacterial extracellular protease. Food Chem. 2018, 248, 346-352. [CrossRef] [PubMed]

55. Sheih, I.C.; Wu, T.K.; Fang, T.J. Antioxidant properties of a new antioxidative peptide from algae protein waste hydrolysate in different oxidation systems. Bioresource Technol. 2009, 100, 3419-3425. [CrossRef] [PubMed]

56. Gimenez, B.; Aleman, A.; Montero, P.; Gomez-Guillen, M.C. Antioxidant and functional properties of gelatin hydrolysates obtained from skin of sole and squid. Food Chem. 2009, 114, 976-983. [CrossRef]

57. Zhu, C.Z.; Zhang, W.G.; Zhou, G.H.; Xu, X.L.; Kang, Z.L.; Yin, Y. Isolation and identification of antioxidant peptides from Jinhua ham. J. Agric. Food Chem. 2013, 61, 1265-1271. [CrossRef]

58. Ren, J.Y.; Zhao, M.M.; Shi, J.; Wang, J.S.; Jiang, Y.M.; Cui, C.; Kakuda, Y.; Xue, S.J. Purification and identification of antioxidant peptides from grass carp muscle hydrolysates by consecutive chromatography and electrospray ionization-mass spectrometry. Food Chem. 2008, 108, 727-736. [CrossRef]

59. Chen, C.; Chi, Y.J.; Zhao, M.Y.; Lv, L. Purification and identification of antioxidant peptides from egg white protein hydrolysate. Amino Acids 2012, 43, 457-466. [CrossRef]

60. Nimalaratne, C.; Bandara, N.; Wu, J. Purification and characterization of antioxidant peptides from enzymatically hydrolyzed chicken egg white. Food Chem. 2015, 188, 467-472. [CrossRef]

(C) 2019 by the authors. Licensee MDPI, Basel, Switzerland. This article is an open access article distributed under the terms and conditions of the Creative Commons Attribution (CC BY) license (http:// creativecommons.org/licenses/by/4.0/). 